WeLleR, J. I. (1994): Economic Aspects of Animal Breeding. ChapmanandHall. $244 \mathrm{p}$.

Whittock, S. P., B. L. Greaves and L. A. Apiolaza (2004): A cash flow model to compare coppice and genetically improved seedling options for Eucalyptus globulus pulpwood plantations. Forest Ecology and Management 191: 267-274.

Whittock, S. P., G. W. Dutkowski, B. L. Greaves and L. A. ApiolazA (2007): Integrating ravenues from carbon sequestration into economic breeding objective for Eucalyptus globulus pulpwood production. Annals of Forest Science 64: 239-246.

Wolfova, M., J. Wolf, J. Pribyl, R. Zahradkova and J. KICA (2005): Breeding objectives for beef cattle used in different production systems: 1. Model development. Livestock Production Science 95(3): 201-215.

WU, H. X. and C. C. YING (1997): Genetic parameters and selection efficiencies in resistance to western gall rust, stalactiform blister rust, needle cast and sequoia pitch month in lodgepole pine. Forest Science 43: 571-581.

WU, H. X., J. L. YANG, M. Ivković, T. A. McRaE and M. B. Powell (2007): Efficiency of Early Selection for Rotation-aged Microfibril Angle and Modulus of Elasticity in Radiata Pine. Annals of Forest Science 64(1): 1-9.

YAMADA, Y. (1995): Are economic selection indices always superior to a desired gains index? Theoretical and Applied Genetics 91: 655-658.

\title{
Response to Selfing in Seed Set, Seedling Establishment and Nursery Growth Based on Controlled Crosses of Abies nordmanniana Clones
}

\author{
By Ulrik BräUner Nielsen*) and Ole Kim Hansen
}

Danish Centre for Forest, Landscape and Planning, Faculty of Life Sciences, University of Copenhagen, Denmark. Hørsholm Kongevej 11, DK-2970 Hørsholm

(Received $15^{\text {th }}$ April 2009)

\begin{abstract}
Nordmann fir (Abies nordmanniana) is used for production of high value Christmas trees in short rotation. Potentially all trees are intended to be sold - no thinnings are normally applied. A high proportion of saleable trees per ha is the main key to secure economic return to the growers. Consumers demand a symmetric and rather uniform tree and, dependent on local traditions, it should be more or less dense and narrow. In Denmark, breeding of Nordmann fir and establishment of seed orchards focus on seed supply and improved Christmas tree quality - aiming at adaption and a rather uniform ideotype Christmas tree. Benefits from employing rather few clones, to maximise gain and uniformity, may potentially be counteracted by increased selfing. The objective of this study was to quantify the effect of selfing on percentage of filled seed and nursery establishment of seedlings. Inbreeding depression was seen for filled seeds (40\%), growth traits (5-17\%), plus mortality and axial damage (5-12 percent units). Many selfed seedlings survive and develop into marketable seedlings, although with a depression in numbers of $23-37 \%$, or $9-12$ percent units. Nursery sorting procedures can only partially reduce the number of inbred seedlings in Nordmann fir. The large variation among clones in the response to selfing indicates that knowledge of the behaviour of selfed progeny from specific clones in 'small number seed orchards' is of practical
\end{abstract}

*) Corresponding author's E-Mail: ubn@life.ku.dk interest. Trade-offs between increased gain by selection of few clones and a penalty paid for increased inbreeding need further studies during a full Christmas tree rotation.

Key words: Seed orchard, selfing, filled seeds, inbreeding depression, nursery practice, Christmas tree.

\section{Introduction}

Nordmann fir (Abies nordmanniana (Stev.) Spach) is the most important Christmas tree species (in numbers sold) in Europe, and has been shown an increasing interest in North America too. In Denmark, breeding activities have been carried out since 1992 (NIELSEN, 2000, 2008) and seed orchards are now entering the stage where they produce commercial quantities of seed (Ditlevsen, 2007, pers. comm.).

Nordmann fir is an exotic tree species to Denmark and is used as a short rotation crop harvested after 10 years, often on farm land. Because of the short rotation there is no need for keeping high genetic variation within the seed production populations (clonal seed orchards) to secure long term stability in the stands coming out of the seed. Furthermore, the small size of the Christmas trees means that thinning is normally not done in the production stands and that every tree in the stand potentially is the final saleable product. Therefore, any cause that delays the attainment of the end product or diminishes the quality is of major inter- 
est. And opposite to normal conifer forestry stands, unfit (e.g. inbred) trees are not to be culled away during the normal growing scheme.

Gains in breeding through selection is obviously improved by high selection intensity, but may also potentially be counteracted by increased selfing and other seed orchard dysfunctions if too low numbers of clones are used in seed orchards. In many conifers, inbreeding depression is quite severe (e.g. HEDRICK et al., 1999), and studies of selfing in some Abies species has shown reduction in seed production (KORMUTAK, 1996; KormutaK and Lindgren, 1996; SorEnsen et al., 1976) as well as reduced growth rate (SORENSEN et al., 1976). Both are unwanted characteristics because they either reduce efficiency in orchard production of seed, or delay or deteriorate the Christmas tree crop.

Traditionally, bare-root plants have been used in Danish forestry and Christmas tree production, but recently there has been an increasing interest for using containerised seedlings, e.g. the Jiffy plug system (BENFELDT and BENTSEN, 2005). Plug production systems generally use highly sorted seed to secure high germination rates, and apply less culling of plants compared to traditional bare root nursery practice. The latter increases the possibility for selfed individuals to pass the nursery production without being culled. Thus, inbreeding potentially impacts seed set as well as nursery production and later potential efficiency of Christmas tree plantations. This study focuses on the quantitative response to inbreeding in Nordmann fir seed, and nursery production based on a set of controlled crosses involving clones from the Danish Christmas tree breeding programme.

More specifically, the objective is to quantify possible inbreeding depression in numbers of filled seeds, germination, survival, growth and seedling quality, and further to look for variation among clones in inbreeding depression. The potential influence of inbreeding depression on genetic narrow clonal seed orchards and nursery practice is also discussed.

\section{Materials and Methods}

\section{Mating design}

A partial diallel using selfing and two pair crossings were applied for a total of 7 clones (Table 1). Further, every clone was pollinated with a pollen mix of 5 other clones (not included in the diallel) - all equally represented based on weight. This gave a total of 7 selfed (self), 14 pair crossings (pc), and 7 crossings based on a pollen mixture (poly). Crossings on each ramet were kept separately, which in total resulted in 52 seed lots from 23 ramets.

\section{Collection, extraction and storage of pollen}

Branches with male strobili were collected from selected plus-trees included in the breeding program, either in the approved Danish seed stands F.526 and F.527 (located in Tversted Dune Forest, department 599 and 623 respectively) or, depending on pollen production, from a grafted seed orchard. The branches were collected in May 2003, and pollen extraction commenced the day after according to the methods normally used at the Arboretum in Hørsholm (NIELSEN and HANSEN, in prep.). After extraction, the pollen was freeze dried in a Leybold-Heraeus GT2 freeze dryer in order to improve freeze storage and facilitate the preparation of pollen mixtures, based on weight, in correct proportions. The pollen was then stored at minus $20^{\circ} \mathrm{C}$ until May 2004, when pollen mixtures for the pollinations were prepared by the use of a balance.

\section{Seed orchard and crossing procedure}

The pollinations were conducted in the clonal seed orchard FP259, Silkeborg State Forest District, established 1993-94, situated in Jutland, just east of Silkeborg. The FP259 consists of 94 clones from the approved Danish seed stands F.526 and F.527 ( $1^{\text {st }}$ generation from directly imported seeds) and the seed stand Lilleheden dept. $852 \mathrm{c}$ ( $2^{\text {nd }}$ generation from directly imported seeds, approval no. F.525 Uggerby). All the clones which are included in the breeding programme were selected for appearance of foliage. Until now the target number of clones in existing orchards after genetic thinning has usually been 15-30 clones - depending on spacing of grafts.

Female flowers were isolated April 27-29, 2004, using terylene bags and water repellent cotton wool. Flowers were isolated on 7 different clones in the clonal seed orchard, chosen due to their high number of female flowers. Pollinations were performed twice - on May 4 and 6 , see mating design in Table 1 . Bags were removed again on June 6 , and cones were harvested September 28 and put into nets comprising each seed lot. After harvesting, the nets with cones were moved to a barn and hung on wires to secure air movement around the nets, and kept at approximately $10^{\circ} \mathrm{C}$, until October 19 , then transferred indoors to a table of hard-cloth-wire to disin-

Table 1. - Mating design. For each crossing combination the number of seed lots is given.

$$
\text { Males }
$$

\begin{tabular}{|c|c|c|c|c|c|c|c|c|c|}
\hline & \multicolumn{9}{|c|}{ Pollen } \\
\hline & & C10 & $\mathrm{C} 13$ & C2O & C26 & $\mathrm{C} 67$ & $\mathrm{C} 72$ & $\mathrm{C} 73$ & poly \\
\hline & C10 & 2 & & & & & 2 & 2 & 1 \\
\hline & C13 & 1 & 5 & & & & & 1 & 2 \\
\hline female & $\mathrm{C} 20$ & 1 & 2 & 2 & & & & & 3 \\
\hline clone & C26 & & 1 & 2 & 2 & & & & 1 \\
\hline & C67 & & & 2 & 2 & 3 & & & 1 \\
\hline & C72 & & & & 2 & 2 & 1 & & 3 \\
\hline & $\mathrm{C73}$ & & & & & 2 & 2 & 1 & 1 \\
\hline
\end{tabular}


tegrate at $18-20^{\circ} \mathrm{C}$ until November 18 . Then, seeds were cleaned by hand using a small rotating drum which allows seed to separate from cone parts. Seed were de-winged gently by hand and then kept at $5{ }^{\circ} \mathrm{C}$ until stratification and germination. A total of 146 pollination bags were pooled into 52 seed lots.

\section{Numbers of filled seeds}

The number of filled seeds in each seed lot was examined with a fine-focus X-ray microscope, X-tek Systems, Tring, UK using $27-28 \mathrm{kv}$ and $46 \mu \mathrm{A}$ radiation. For the 52 seed lots a pooled total of approximately 105 seeds (based on three subsamples of about 35 seeds), were used for rating each seed into two groups, either 1: filled (seeds appearing with a dark shadow or lighter shadow on X-ray photo), or 2: empty (no shadow - seeds appear to be empty). For 20 of the 52 seed lots an extra seed sample (105 seeds) was evaluated - giving a total of 72 seed sample estimates. Percent of filled seeds was calculated as the number of group 1: filled seeds out of total number of seed X-rayed per seed lot. Regrettably, nongerminating seeds in the boxes were not cut as a control of filled seeds. The visual evaluation method of X-ray photos of seed lots in most cases gave an easy distinction between clearly empty seeds and filled seeds, however, some intermediates were present, which could lead to some misjudgement of filled versus empty - in general leading to a weak underestimation of filled seeds. A single sample of 2 filled seeds according to the X-raying, later showing 4 germinating seeds, was omitted from the data analysis as an outlier. All 72 seed samples from the X-ray study were kept separately during stratification, and were later placed in separate germination boxes/plastic bags - there was thus no removal of empty seeds based on X-raying before germination.

\section{Germination and sowing}

Seed stratification was initiated at the beginning of February 2005, keeping each of the 72 samples separate. For the germination test, two methods were applied: A) Germination boxes, recommended by MARTIN JENSEN (MARTIN JENSEN pers. comm.), based on a plastic box from Ultraplast (www.ultraplast.dk) type A6/60 (60 samples), and B) The seed was wrapped in moist filter paper and placed in plastic bags (12 samples).

Seed was kept refrigerated at $5^{\circ} \mathrm{C}$ and started to germinate after 9-10 weeks, which is more or less in accordance with GosLing et al. (1999). Seeds were sown in plugs. A standard Jiffy $200 \mathrm{~cm}^{3}$ peat plug placed in $6 \times 6$ plastic frames was used. Only seed showing clear swelling or visible radicle profusion was transferred from germination boxes/plastic bags to the plugs. Day of sowing was registered for all seeds. Furthermore, seed development at sowing was rated: t: only the very tip of the radicle could be seen, $\mathrm{s}$ : a short radicle about $1-3 \mathrm{~mm}, \mathrm{~m}$ : medium radicle $3-5 \mathrm{~mm}$, and $\mathrm{l}$ : a long radicle over $5 \mathrm{~mm}$. These were transformed into approximate radicle lengths at time of sowing: $\mathrm{t}=0.5 \mathrm{~mm}, \mathrm{~s}=2$ $\mathrm{mm}, \mathrm{m}=4 \mathrm{~mm}$ and $\mathrm{l}=6 \mathrm{~mm}$.

Each seed was sown in a separate plug and covered with a thin layer of fine washed sand to prevent drying. Frame number and position within frame was regis- tered. Sowing was done every $2-5$ days depending on the speed of germination, from June 15 to August 1 2005.

\section{Experimental design nursery plug-trial}

Seeds were sown successively when germinating. All seeds from a sample (box/plastic bag) at a given day were placed in consecutive frame positions, which means some grouping in the frames of seeds from a genetic unit on a specific day. However, each plug was air pruned and therefore considered to be a single unit within a frame. Across days of sowing, all genetic units were approximately randomised across all frames, although confounding effects were present for increased frame number and day of germination. Statistically, the seedlings were organised and treated as a randomised incomplete block design with single tree plots in blocks of 36 plants (i.e. a single frame), in a total of 76 blocks (frames).

\section{Seedling production}

Seedlings were initially sown in a greenhouse, and during the summer months were grown under shade cloth outdoors, and were from November until spring kept in a non-heated greenhouse. Standard irrigation and fertilisation schemes were used. Severe problems with fungus (Fusarium ssp.) were experienced during the first growing season, and all seedlings were treated twice during the first summer with Octave ${ }^{\circledR}(461,4 \mathrm{~g} / \mathrm{kg}$ prochloraz) from BASF. Plants were moved outdoors to lower humidity level, and plants which showed fungus attack (dead or wilting) were removed in order to reduce the spore level. Conifer seed has been shown to harbour Fusarium inoculum (AxELROOD et al., 1995), and Fusarium ssp. is a well known problem in nursery production for a wide variety of species, including Nordmann fir. The seed borne inoculum can also be a part of the explanation of the severe damage in a sterilised growth media - because no seed treatment was applied before sowing. From nursery practice 5-6000 seedlings from a seedlot of $12-15,000$ seeds per $\mathrm{kg}$ is not uncommon (MARTIN JENSEN pers. comm.) - or about one third of the seed meet market demand for a seedling. Some maternal influence on the damage might be present although soaked before stratification in the same water tank which might even out the infection level (NEUMANN et al., 1997), but the relative comparisons of types of crossings, often within ramet, was not expected to be influenced.

\section{Measurements on seedlings}

First measurement: Height (mm) year 1 and 2, number of needles in the transition zone between the two years growth, forking i.e. numerous leaders, no budbreaking/flushing buds, mortality and browning on needles due to fungal attack. These measurements were carried out after the second year's height growth.

After the $3^{\text {rd }}$ growth season (September 18 2007): Height ( $\mathrm{mm}$ ), number of buds at the terminal shoot and colour of the plant were evaluated; the latter using a score from 1 to 3 were 1: light green/yellowish, 2: green, and 3: dark green, and also analysed as a binomial vari- 
able meaning 1: was a light green/yellowish individual, and 0 : normal colour of the plant.

\section{Statistics}

The focus of this study was to compare the performance of the selfed indiviuals compared to two types of outcrossed material (pair crosses and polymix). Therefore, despite the diallel design, a simplified model was used, following the arguments of SKRøPPA (1996).

\section{Part A. Filled seed and germination}

Data from the $72 \mathrm{X}$-rayed seed samples included total number of seeds, filled seeds and germinated seeds per sample.

Proportion of filled seeds and proportion of germinating seed out of the total number of seeds, as well as of the number of filled seeds, were analysed using the following model:

$$
\text { Model } \mathrm{Y}=\mu+\mathrm{T}+\mathrm{C}+\mathrm{T} \times \mathrm{C}+\mathrm{e}
$$

Where $\mathrm{Y}$ is proportion, $\mu$ is overall mean, $\mathrm{T}$ is type of crossing (self vs. pooled value of pair crossing and pollen mixture), $\mathrm{C}$ is clone, $\mathrm{T} \times \mathrm{C}$ is the interaction type of crossing and clone, and e is the residual. Type of crossing, and clone, were treated as fixed effects and residual variation assumed to be random.

Because some seed lots had two or more samples, an average value of each seed lot was calculated. Germination method (box or plastic bag) had no influence on germination. A total of 52 observations were available for the filled seed analysis.

\section{$\underline{\text { Part B nursery trial - plug seedlings }}$}

Measured seedling traits were analysed using the model:

$$
\text { Model } \mathrm{Y}=\mu+\mathrm{f}+\mathrm{T}+\mathrm{C}+\mathrm{T} \times \mathrm{f}+\mathrm{T} \times \mathrm{C}+\mathrm{e}
$$

Where $\mathrm{Y}$ is observed value, $\mu$ is overall mean, $\mathrm{f}$ is frame number used as blocks and identical to batch of sowing, $\mathrm{T}$ is type of crossing (self, pair crossing or pollen mixture), $\mathrm{C}$ is effect of clone (mother), $\mathrm{T} \times \mathrm{f}$ interaction between frame and type, $\mathrm{T} \times \mathrm{C}$ is the interaction between clone and type of crossing and e is the residual. Type of crossing, clone and clone $x$ type of crossing were considered as fixed effects, others were assumed to be random.

Statistical analyses were carried out using the MIXED procedure in the SAS program package vers. 9.1. Least square means of fixed effects were calculated and tested using the Satterthwaite's option. Model assumptions of normally distributed residuals and homogeneity of variance were tested by normality plots and plotting standardised residuals against predicted values using the procedures UNIVARIATE and PLOT. Unless otherwise mentioned, assumptions were fulfilled to a satisfactory degree. Residuals of data having a binomial nature, i.e. dead/alive were not normally distributed, but homogeneity of variance was acceptable.

For comparison of the performance of the selfings compared to the outcrossed a ratio was calculated based on least square means of selfed divided by mean of out- crossed, i.e. pollen mix and pair crosses. Inbreeding depression was calculated according to SORENSEN et al. (1976) as (1-ratio)*100.

\section{Results}

\section{Filled seeds and germination}

Based on the X-ray analysis, there were a lower number $(p=0.030)$ of filled seeds in the selfed families compared to the pooled effect of pair crosses and pollen mix (Table 2) respectively $15.5 \%$ and $26.0 \%$ - meaning an inbreeding depression in average of 10.5 percent units or $40 \%$. Similar results were seen for germinated seeds, Table 2. No significant differences were seen in the germination of the filled seeds - which for both groups were of the same magnitude and rather high (>90\%). Day of sowing, which approximately is the same as date of germination, showed no overall differences between selfs and outcrossings and neither any differences in length of embryo at sowing were seen (Table 2 and Figure 1). However, for both traits, clonal effect and interaction between type of crossing and clone were present. Therefore, it can be summarised, that inbreeding depression was expressed in numbers of filled seeds, but not for the ability of the filled seeds ultimately to germinate.

\section{Seedling production}

Height growth showed an increased inbreeding depression from $5 \%$ in year one to $15 \%$ after three years. For number of buds, a similar inbreeding depression of $17 \%$ was seen after three years (Table 3). Despite a significant interaction, the picture was fairly stable except for a few combinations of clone and type of crossing, Figure 2. For colour score, an inbreeding depression of $11 \%$ was seen, or evaluated as frequency of more yellowish poor looking seedlings; selfed individuals showed 8 percent-units more individuals with poor colour than outcrossed, Table 3 and Figure 2, and no interaction between clone and type of crossing were seen, Table 3 and Figure 2. Number of needles after two growing seasons showed clonal differences and some interactions, but no overall differences between types of crossing, Table 3 and Figure 2.

Mortality after 2 years was rather high and on average nearly two thirds of the trees died mainly due to the fungal attack shortly after sowing (clonal range $50 \%$ to $80 \%$ ). The mortality was clone and type dependent, Table 3 and Figure 2, but an inbreeding depression on average of $11 \%$ or 7 percent units was seen across clones - although hardly significant $(p=0.070)$. Remnants of the fungal attack were registered on surviving seedlings as brown spots on the needles, but no inbreeding depression was seen. Again, large differences between clones were seen which to some extend was opposite to the mortality.

Damage to the leader, either as a dead terminal bud or as forking, showed an inbreeding depression of $18 \%$ or 5 percent-units, Table 3. Clone had also for this combined trait a strongly significant influence, Figure 2, and especially two clones suffered from poor axial development. 
Table 2. - Mean values (least square means) and analysis of variance for filled seed, germination of filled seeds and germination of total number of seeds evaluated. Results showing least square mean values of outcrosses versus selfings and p-levels of fixed effects. Day of sowing and radicle length was based on germination from all seed lots including those X-rayed.

\begin{tabular}{|c|c|c|c|c|c|}
\hline \multirow[t]{2}{*}{ Trait: } & \multirow{2}{*}{$\begin{array}{r}\text { Filled seeds }^{*} \\
\text { pct. }\end{array}$} & Germination* & Germ of filled $^{*}$ & \multirow{2}{*}{$\begin{array}{r}\text { Day of } \\
\text { sowing } \\
\text { no. }\end{array}$} & \multirow{2}{*}{$\begin{array}{r}\text { Radicle } \\
\text { length } \\
\mathrm{mm}\end{array}$} \\
\hline & & pct. & pct. & & \\
\hline Lsmeans & & & & & \\
\hline pair crosses & 26,0 & 24,1 & 93,5 & 32,4 & 3,9 \\
\hline pollen mix & & & & 32,3 & 3,9 \\
\hline selfings & 15,5 & 15,0 & 93,5 & 32,2 & 4,0 \\
\hline Ratio & 0,60 & 0,62 & 1,00 & 0,99 & 1,01 \\
\hline \multicolumn{6}{|l|}{ P-levels } \\
\hline Type & 0,030 & 0,044 & 0,989 & 0,470 & 0,854 \\
\hline Clone & 0,351 & 0,343 & 0,380 & $<0.001$ & $<0.001$ \\
\hline Type $x$ clone & 0,431 & 0,292 & 0,657 & $<0.001$ & $<0.001$ \\
\hline
\end{tabular}

* analysis based on a pooled value of pollen mix and pair crosses.

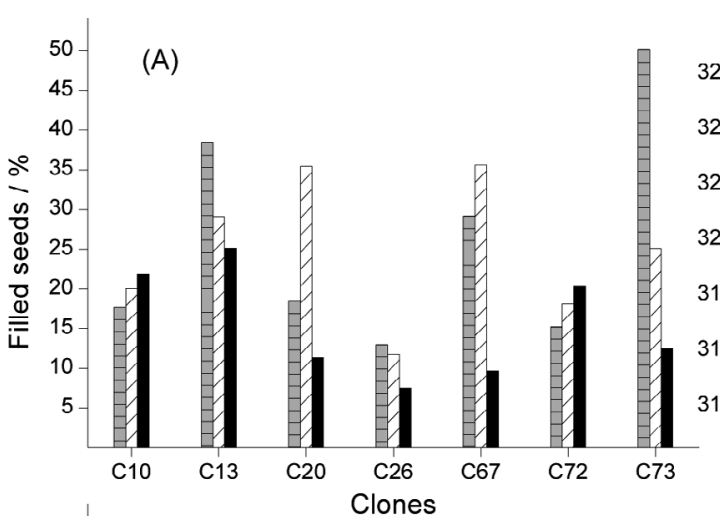

(B)
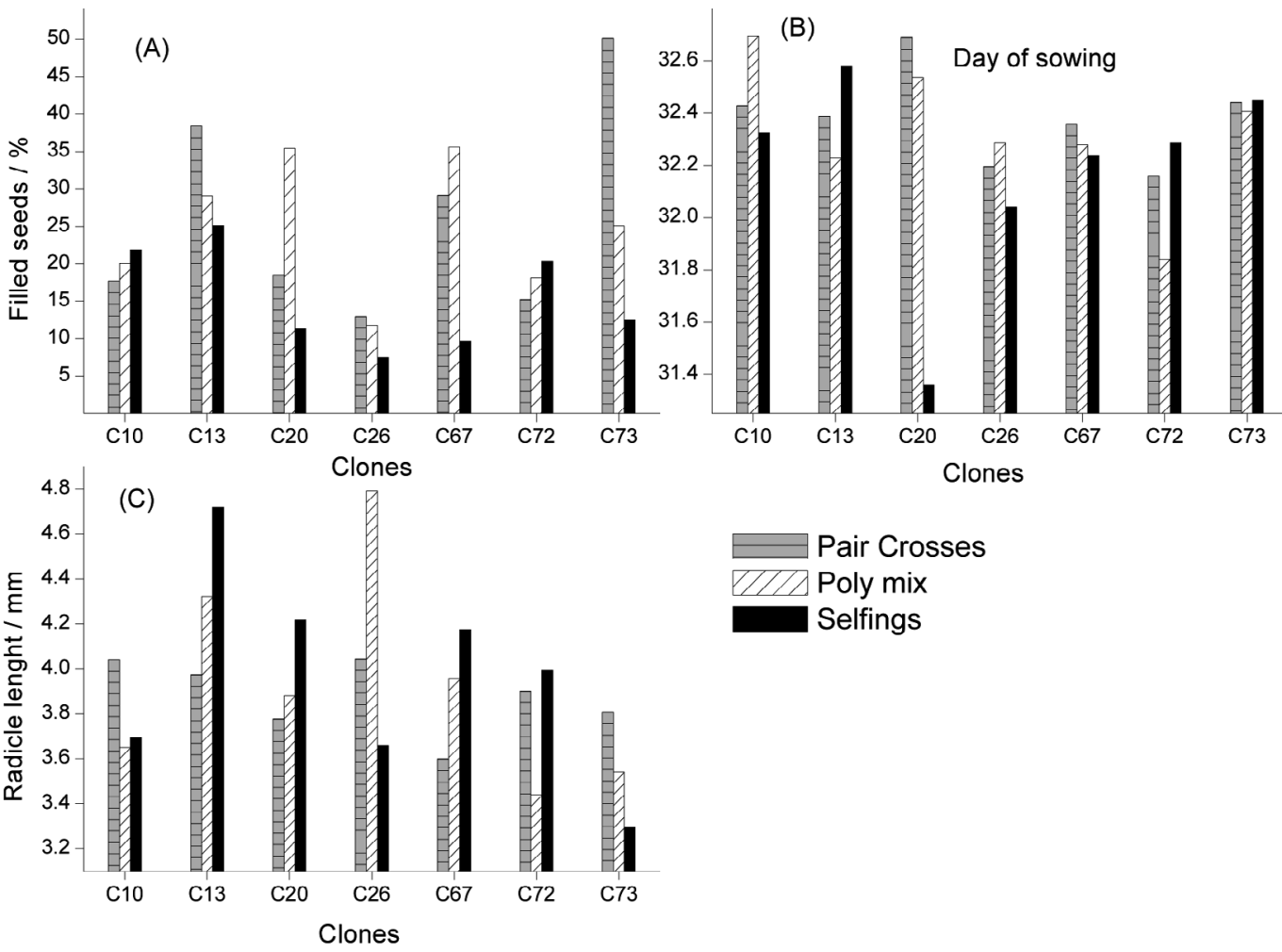

Figure 1. - Clonal mean values of the influence of crossing types on filled seeds and germination Symbols: Gray columns with horizontal lines = pair crosses; Columns with oblique lines = poly mix; Filled columns = selfings. A) Filled seeds in percentage, B) Day of sowing (- days from sowing of first seed), C) Radicle length in $\mathrm{mm}$.

From a production point of view, it would be interesting to see how many seedlings which are saleable dependent on type of crossing, hence two selections were evaluated. Selection I: A living seedling with straight stem and good colour (not yellow), and Selection II: As Selection I but further demands a height above $80 \mathrm{~mm}$. An inbreeding depression in saleable plants of 9 to 12 percent-units was seen for the two selections, or $23 \%$ to $37 \%$, Table 3 .
For evaluating the specific clones in this study, the response to selfing for selected traits was estimated as the ratio between selfs and average of outcrosses, Table 4. Large clonal differences were seen from trait to trait. Progeny from clone C72 showed the most drastic survival response to inbreeding, $40 \%$ surviving selfed seedlings compared to outcrossed (all based on filled seeds). However, the surviving selfed seedlings grew on average just as well as the outcrossed seedlings. By con- 
Table 3. - Mean values (least square means) and ANOVA statistics of crossing types: selfing, pair crossings, and pollen mix. Traits measured: Height 2007 (3y), height 2006 (2y) and height 2005 (1y), at 2y: Number of needles, trees with needles damaged by fungus - Browning, seedling mortality, forking, terminal bud dormant or dead, number of buds at end of terminal leader (3y) and average colour of needles (3y). Saleable seedlings I - criteria straight stem and green colour, Saleable seedlings II - criteria height above $80 \mathrm{~mm}$, straight stem and green colour. Ratio: selfs divided by average of outcrossed, p-values for statistics of fixed effects.

\begin{tabular}{|c|c|c|c|c|c|c|c|c|c|c|c|c|c|c|}
\hline \multirow[t]{2}{*}{ Trait: } & \multicolumn{3}{|c|}{ Height } & \multirow{2}{*}{$\begin{array}{r}\text { Buds } \\
3 y \\
\text { no. }\end{array}$} & \multirow{2}{*}{$\begin{array}{r}\text { Needles } \\
2 y \\
n o .\end{array}$} & \multirow{2}{*}{$\begin{array}{r}\text { Colour } \\
\text { score } \\
3 y \\
\text { score }\end{array}$} & \multirow{2}{*}{$\begin{array}{r}\text { Colour } \\
\text { yellow } \\
3 y \\
\text { freq. }\end{array}$} & \multirow{2}{*}{$\begin{array}{r}\text { Mortality } \\
2 y \\
\text { freo. }\end{array}$} & \multirow{2}{*}{$\begin{array}{r}\text { Browning } \\
2 y \\
\text { freq. }\end{array}$} & \multirow{2}{*}{$\begin{array}{r}\text { Leader } \\
\text { damage } \\
2 y \\
\text { freq. }\end{array}$} & \multirow{2}{*}{$\begin{array}{r}\text { Dead } \\
\text { top bud } \\
2 y \\
\text { frea. }\end{array}$} & \multirow{2}{*}{$\begin{array}{r}\text { Forking } \\
2 y \\
\text { freq. }\end{array}$} & \multirow{2}{*}{$\begin{array}{c}\text { Saleable seedlings } \\
1 \\
3 y \\
\text { freq. }\end{array}$} & \multirow[b]{2}{*}{$\begin{array}{r}11 \\
3 y \\
\text { freq. }\end{array}$} \\
\hline & 1y & $2 y$ & $3 y$ & & & & & & & & & & & \\
\hline Lsmeans & & & & & & & & & & & & & & \\
\hline pair crosses & 40 & 63 & 118 & 2,9 & 11,8 & 2,7 & 0,06 & 0,60 & 0,12 & 0,03 & 0,02 & 0,02 & 0,36 & 0,32 \\
\hline pollen mix & 40 & 63 & 121 & 2,7 & 11,7 & 2,8 & 0,06 & 0,58 & 0,18 & 0,06 & 0,03 & 0,04 & 0,38 & 0,33 \\
\hline selfings & 38 & 59 & 101 & 2,3 & 11,7 & 2,4 & 0,14 & 0,65 & 0,18 & 0,10 & 0,04 & 0,06 & 0,29 & 0,21 \\
\hline Out cross ${ }^{*}$ & 40 & 63 & 119 & 2,8 & 11,7 & 2,7 & 0,06 & 0,59 & 0,15 & 0,05 & 0,02 & 0,03 & 0,37 & 0,33 \\
\hline difference $^{* *}$ & 2 & 4 & 18 & 0,48 & 0,02 & 0,3 & $-0,08$ & $-0,07$ & $-0,03$ & $-0,05$ & $-0,02$ & $-0,03$ & 0,09 & 0,12 \\
\hline ratio & 0,95 & 0,93 & 0,85 & 0,83 & 1,00 & 0,89 & 2,33 & 1,11 & 1,21 & 2,18 & 1,95 & 2,17 & 0,77 & 0,63 \\
\hline \multicolumn{15}{|l|}{ P-fevels } \\
\hline type & 0,004 & 0,001 & $<0.001$ & $<0.001$ & 0,984 & $<0.001$ & 0,028 & 0,070 & 0,175 & 0,006 & 0,254 & 0,032 & 0,009 & $<0.001$ \\
\hline clane & $<0.001$ & $<0.001$ & $<0.001$ & $<0.001$ & $<0.001$ & 0,006 & 0,072 & $<0.001$ & $<0.001$ & $<0.001$ & $<0.001$ & 0,011 & $<0.001$ & $<0.001$ \\
\hline type $x$ clone & 0,010 & 0,021 & 0,007 & 0,006 & $<0.001$ & 0,735 & 0,436 & $<0.001$ & 0,005 & 0,004 & 0,002 & 0,086 & $<0.001$ & $<0.001$ \\
\hline column & 1 & 2 & 3 & 4 & 5 & 6 & 7 & 8 & 9 & 10 & 11 & 12 & 13 & 14 \\
\hline
\end{tabular}

* Mean of pair cross and polymix.

*** Difference between average out of crossed and selfed individuals.
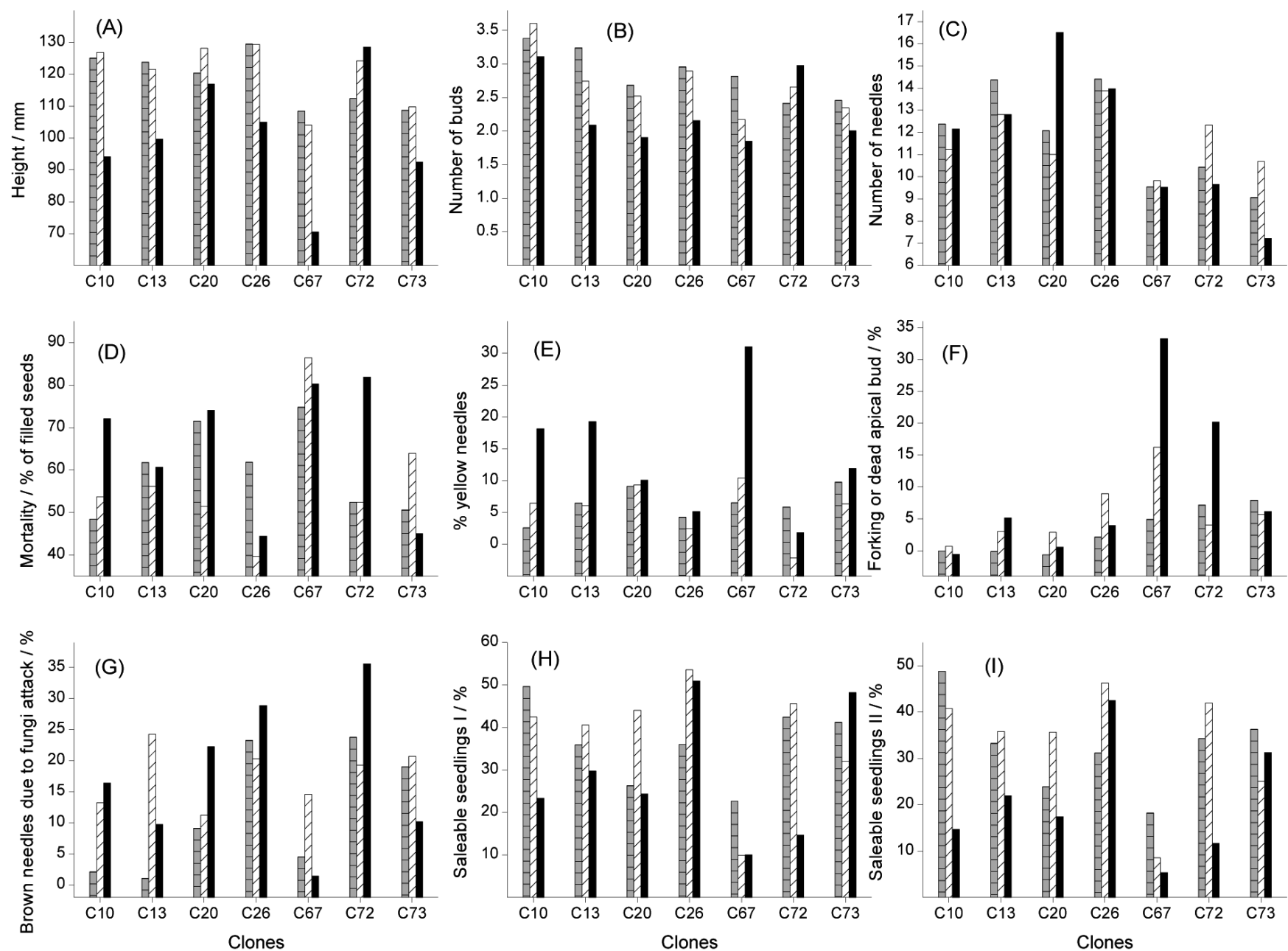

(I)

Figure 2. - Clonal mean values of the influence of crossing types on filled seeds and germination. Gray columns with horizontal lines = pair crosses; Columns with oblique lines = poly mix; Filled columns = selfings. A) Height after 3 years in mm, B) Number of buds, 3 year, C) Number of needles, 2 year, D) Mortality after 2 years in percentage of filled seeds, E) Colour of seedlings - percent seedlings with yellow needles, 3 year, F) Forking (multiple leaders) or dead apical bud, 2 year G) Browning of needles due to fungal attack, 2 year, H) Commercial seedlings I in percentage - criteria: straight stem and not yellow, 3 year, I) Commercial seedlings II in percentage - criteria: height above $80 \mathrm{~mm}$, straight stem and not yellow, 3 year. 
Table 4. - Clonal values for the ratio between selfs and outcrosses. Traits: Height 3 years (3y), survival 2 years (2y), number of buds 3 years (3y), and colour (3y).

\begin{tabular}{cccccc}
\hline Clone & Height 3y & Survival 2y & Buds 3y & Colour 3y & Average \\
\hline C10 & 0,74 & 0,56 & 0,89 & 0,87 & 0,77 \\
C13 & 0,81 & 0,90 & 0,69 & 0,81 & 0,80 \\
C20 & 0,99 & 0,75 & 0,75 & 1,04 & 0,88 \\
C26 & 0,78 & 1,14 & 0,72 & 0,92 & 0,89 \\
C67 & 0,65 & 1,04 & 0,73 & 0,78 & 0,80 \\
C72 & 1,08 & 0,40 & 1,19 & 1,02 & 0,92 \\
C73 & 0,84 & 1,23 & 0,84 & 0,93 & 0,96 \\
\hline
\end{tabular}

Table 5. - Effect of sorting plugged seedlings after 3 years of production based on criteria for height $(\mathrm{H})$ in $\mathrm{mm}$ and number of buds (buds) on the terminal leader. Numbers are percentages of remaining plants after sorting in the nursery.

\begin{tabular}{lccccccc}
\hline Type & $\begin{array}{c}\text { No } \\
\text { selection }\end{array}$ & $\mathrm{H}>100$ & $\begin{array}{c}\mathrm{H}>100 \\
\text { \& buds }>=3\end{array}$ & $\mathrm{H}>110$ & $\begin{array}{c}\mathrm{H}>110 \\
\text { \& buds }>=3\end{array}$ & $\begin{array}{c}\mathrm{H}>120 \\
\begin{array}{c}\mathrm{H}>120 \\
\text { buds }>=3\end{array}\end{array}$ \\
\hline pair crosses & 100 & 74 & 54 & 59 & 46 & 44 & 37 \\
pollen mix & 100 & 80 & 54 & 71 & 50 & 57 & 41 \\
selfings & 100 & 48 & 28 & 34 & 23 & 28 & 20 \\
\hline
\end{tabular}

trast, selfings from C73 had a very good survival rate, but a moderate reduction in growth, number of buds and needle colour.

In nurseries, the sorting or culling of seedlings is normally applied to meet standards for commercial plants sent on to market. Different sets of criteria were applied, Table 5, and e.g. setting criteria of height above $100 \mathrm{~mm}$ and minimum 3 buds at the apical shoot would reduce the number of selfed individuals to $28 \%$, while the outcrosses only would be reduced to $54 \%$ - meaning that selection is nearly twice as impactive on selfed compared to outcrossed seedlings. This proportion was rather stable across other threshold values, Table 5 .

\section{Discussion}

Nordmann fir differs substantially from other conifers grown in temperate forestry by the short rotation time, a growing scheme without thinning and each tree being the final end-product. Economically Christmas tree production is highly dependent on a high tree take-out.

In general, consumers demand a symmetric and rather uniform tree and dependent on local traditions a more or less dense and narrow tree (KAJ ØsTERGAARD, pers. comm.). The objective is therefore the production of an ideotype Christmas tree with some slight modifications for different markets. The short rotation and clearcut of the Christmas tree fields does not call for a large genetic variation in the production stands for long term stability as in traditional forestry. From a breeding point of view, this leads to a demand for rather uniform genetic plant material, meaning few clones, to obtain the highest proportions of the wanted ideotypes (NIELSEN unpublished). One way to achieve this is to use highly selected clonal seed orchards, based on progeny tested material. One major expected problem in reducing the number of clones in seed orchards is the expected increase in inbreeding, either simply due to an increased amount of 'own' pollen from the clones - influencing seed set (LINDGREN and YAZDANI, 1988; YAZDANI and LINDGREN, 1991), quality and seedling mortality, or due to the risk of including clones with a high inbreeding rate among the few selected (HANSEN and KJÆR, 2006).

Earlier studies have reported inbreeding depression in Abies ssp. (HANSEN, 2008; KormutaK and LindGREN, 1996; KoRMUTAK, 1996, 1999; LEDIG et al., 2006 (review); Moulalis, 1986; SorENSEN, 1999; SORENSEN et al., 1976) in height growth and/or seed set, and our results for Nordmann fir seem in general in line with these findings. In our study, inbreeding on average reduced the growth of the seedlings by $15 \%-17 \%$, survival by $5-8$ percent-units and saleable seedlings by $9-12$ percentunits. Therefore there seems no doubt that inbreeding in general also influences the growth of Nordmann fir seedlings, but these findings might impact the seed orchard owners, the nurseries and the Christmas tree growers in different ways.

Empty seeds will first of all reduce the quality of the orchard seed, but not necessarily the income from the seed production unless germination rate is included in the price. Empty Abies seed has traditionally been difficult to sort from filled, however technical methods are currently improved significantly (MARTIN JENSEN, pers. comm.), which in the future might reduce the effect for the nursery - hence maintaining high germination rates, which especially are required for containerised seedling production.

The potential trade-off between genetic gain and drawbacks of inbreeding in low number seed orchards imposes the question - is it possible to establish a seed production based on 1) clones not inbreeding, or 2) clones showing no inbreeding depression for use in such narrow seed orchards? Preferably these clones should be selected among already tested and top ranked clones/ plus-trees from the breeding program. 
Some reports have shown large variation among Douglas fir seed parents in inbreeding depression (Sorensen, 1997; Woods et al., 2002), and HANSEN and KJÆR (2006) found a single clone of Nordmann fir having a large number of inbred seed. SoRENSEN (1997) also identifies that even for traits in which no inbreeding depression in general is seen - single seed parents can show large differences. We found neither significant clonal variation in numbers of filled seed after selfing, nor a difference in germination rates although this might be due to a rather limited study material. However, two quite different types were seen for vigour and survival during seedling production: i) a clone like C72 showing a large depression in survival, but then really no recognisable effect on seedling vigour, ii) a set of clones showing no depression in survival - but more or less depression in vigour. From a nursery point of view, type i) is unwanted, because it will reduce numbers of saleable plants, but the Christmas tree grower will not experience any differences between inbred and outcrossed material - assuming the relative performance is unchanged through a full Christmas tree rotation. The result is vice versa for type ii), because the Christmas tree grower will get a more variable material - but less mortality will be realised in the nursery. Further, nursery practice also impacts these considerations. Our findings indicate that culling diminishes, but does not eliminate the problem of inbred seedlings being introduced into the Christmas tree fields. Obviously, if only minor levels of culling are applied, which is often the case in plug production systems, more selfed seedlings will be brought onto the market. Culling for selfed individuals was very efficient for Douglas fir, with a probability of only $3 \%$ of the selfings to meet market demands (WooDs et al., 2002). Sowing of more than one seed in plugs and thinning of doublets will diminish the problem, following the procedures of Kolotelo et al. (2001) and the mathematics of ScHWARTZ (1993).

So, in Nordmann fir it seems possible to select clones only showing minor inbreeding depression on the cost of survival, but most likely there will be significant numbers of selfed seedlings passing the normal nursery culling standards, and therefore potentially transferred to the Christmas tree fields.

In our study we have no information on actual inbreeding levels in Nordmann fir. A fairly low $\mathrm{F}_{i s}$ level, $6 \%$, was reported by DuccI et al. (1999). This means, if only half the selfed seedlings meet the standards due to culling, that there will only be approximately $3 \%$ inbred seedlings, of which several will probably grow like outcrossed seedlings. This drawback in growth and vitality should be counteracted by selecting the very best trees with the highest breeding values. This problem is comparable with selection of individuals for seed production populations in advanced generation seed orchards focusing on trade-offs between an inbreeding penalty and extra gain by selection of high performing, but related individuals (STOEHR et al., 2008). Based on models in Douglas fir, WANG et al. (2004) found that slightly higher breeding values for related than unrelated clones offset or exceeded the effects of inbreeding resulting from related matings. Tradeoffs between gain and inbreeding depression in Nordmann fir will obviously be more problematic for higher selfing rates and less or no culling during seedling production.

No records were yet available on selfed seedling performance in Christmas tree fields. For seedlings which had passed normal bare-root culling procedure, HANSEN and NiELSEN (in prep.) found that 2\% (12 out of 594 seedlings) were inbreeds. Compared to outcrossed these inbreeds had a $17 \%$ lower height at age 3 from planting (6 y from seed), but no differences in leader damages and number of branches were seen. For Nordmann fir, some nursery effects have been shown to last until rotation with regard to height growth, but no nursery effects lasted for tree width and quality grading (NIELSEN and HANSEN, unpublished). Continued measurements under field conditions of the seedlings presented in this study will help to clarify the effect of inbreeding for the Christmas tree growers.

This study has focused on the effect of inbreeding in seed orchards with a low number of clones. Besides the quantitative effects of inbreeding on the examined characters, a whole set of other aspects also needs consideration before efficient narrow seed orchards can be implemented. This include timing of pollen release and cone receptivity, role of pollen competition against selfing (LINDGREN and YAZDANI, 1988; YAZDANI and LINDGREN, 1991), assortative mating (HANSEN and NIELSEN, 2008), and clonal differences in general flowering ability.

\section{Conclusion}

Inbreeding depression was seen for filled seeds, growth, quality, mortality and axial damage in accordance with other conifer species. As for other Abies ssp., there is a tendency that quite a few seedlings survive and develop, although depressed, into marketable seedlings. Nursery procedures can only partially reduce the number of inbred seedlings in Nordmann fir. The large variation among clones in the response to selfing indicates that knowledge of the behaviour of selfed progeny from specific clones in 'small number seed orchards' is of practical interest for seed orchard managers, nurseries and Christmas tree growers. Trade-offs between increased gain by selection of few clones and a penalty paid for increased inbreeding need further studies during a full Christmas tree rotation.

\section{Acknowledgements}

We would like to thank Carlsens Langes Legatstiftelse for providing financial support to conduct the crossings. We are grateful to Foreningen Plan-Danmark for having financed the production of seedlings, the nursery trial setup, as well as data measurements and subsequent analyses. Silkeborg State Forest district and the Tree Improvement Station, Humlebæk, in Denmark are acknowledged for giving permission to use their clonal seed orchard. We thank KenNeth FredLund, Syngenta Seed AB, Landskrona, Sweden, for advice on X-raying of seed samples and permission to use their equipment, and Martin Jensen, Århus University, for germination boxes, advice on seed handling and for valuable 
comments on the manuscript. Finally, thanks to OLE BYRGESEN and his staff at the Arboretum in Hørsholm for sowing the seeds and subsequently taking care of them.

\section{References}

Axelrood, P. E., D. Neumann, R. Trotter, R. Radley, G. Shrimpton and J. Dennis (1995): Seedborne Fusari$u m$ on Douglas-fir: Pathogenicity and seed stratification method to decrease Fusarium contamination. New For. 9: $35-51$.

BENFELDT, P. and N. S. BENTSEN (2005): Kulturstart i nordmannsgran med dækrods- og barrodsplanter. Extension service information sheet no. 4.9-9. Forest and Landscape, Denmark, 2 pp. (In Danish).

Ducci, F., R. Proietti and J. M. Favre (1999): Allozyme assessment of genetic diversity within the relict Sicilian fir Abies nebrodensis (Lojac.) Mattei. Annals of Forest Science 56: 345-355.

Gosling, P. G., M. Parratt and A. Peace (1999): Identifying the optimum pretreatment duration and germination temperature for Abies nordmanniana [(Steven) Spach] seed, and assessing the effect of moisture content and storage temperature on seed longevity. Seed Science and Technology 27: 951-961.

HANSEN, O. K. and E. D. KJÆR (2006): Paternity analysis with microsatellites in a Danish Abies nordmanniana clonal seed orchard reveals dysfunctions. Canadian Journal of Forest Research 36: 1054-1058.

HANSEN, O. K. (2008): Mating patterns, genetic composition and diversity levels in two seed orchards with few clones - Impact on planting crop. Forest. Ecol. Manag. 256: 1167-1177.

HANSEN, O. K. and U. B. Nielsen (2008): Crossing success in Abies nordmanniana following artificial pollination with a pollen mixture of $A$. nordmanniana and $A$. alba. Silvae. Genet. 57: 70-76.

Hedrick, P. W., O. SAVolainen and K. KarkKainen (1999): Factors influencing the extent of inbreeding depression: an example from Scots pine. Heredity 82: 441-450.

JACOBSEN, F. (1988): Juletræer og Klippegrønt. In: HeNRIKSEN H. A. (Ed.)., Skoven og dens dyrkning. Dansk Skovforening, Nyt Nordisk forlag Arnold Busck, Copenhagen, pp. 607-636.

Kolotelo, D., E. V. Steenis, M. Peterson, R. Bennett, D. Trotter and J. Dennis (2001): Seed handling guidebook. British Columbia Ministry of Forest, Tree Improvement Branch. p115.

KoRMUTAK, A. (1996): The self- and cross-pollination in some species of firs (Abies sp.). Folia Dendrologica 21-22: 319-323.

KoRMUTAK, A. (1999): Self-incompatibility in silver fir (Abies alba). Biologia Bratislava 54: 101-105.

KoRMUTAK, A. and D. LiNDGREN (1996): Mating system and empty seeds in silver fir (Abies alba Mill.). For. Genet. 3: 231-235.

Ledig, F. T., P. D. Hodgskiss and D. R. Johnson (2006): Genetic diversity and seed production in Santa Lucia fir
(Abies bracteata), a relict of the Miocene Broadleaved Evergreen Forest. Conservation Genetics 7: 383-398.

LiNDGREN, D. and R. YAZDANI (1988): Paternal contributions following artificial pollination in Pinus sylvestris (L.). Scand J Forest Res 3: 299-304.

Moulalis, D. (1986): Self-incompatibility and inbreeding of European Fir (Abies alba Mill). Forstwissenschaftliches Centralblatt 105: 487-494.

Neumann, M., D. Trotter and D. Kolotelo (1997): Seed soaking tank sanitation method to reduce risk of contamination of seedlots by Fusarium. British Columbia Ministry of Forests. Seed and Seedling Extension Topics 70 (1 and 2): 17. http://www.for.gov.bc.ca/HTI/ publications/misc/Fung1\%2097SSEN.pdf.

NIELSEN, U. B. (2008): Results from 15 years of breeding for improved quality of Christmas trees and greenery in Denmark. In: Thomsen I. M., RASmussen H. N. and Sørensen J. M. (Eds.): Proceedings of the $8^{\text {th }}$ International Christmas Tree Research and Extension Conference. Forest \& Landscape Working Papers No. 26-2008, 145 pp. Forest \& Landscape Denmark, Hørsholm.

NiELSEN, U. B. (2000): Forædling af nordmannsgran og nobilis: Status og muligheder. Pyntegrøntserien 15: 1-54. Hørsholm, Forskningscentret for Skov \& Landskab. (In Danish).

SCHWARTZ, M. (1993): Germination math: calculating the number of seeds necessary per cavity for a given number of live seedlings. Tree Planters' Notes: 44 (1):19-20.

Skrøppa, T. (1996): Diallel crosses in Picea abies. II. Performance and inbreeding depression of selfed families. For. Genet. 3: 69-79.

Sorensen, F. C., J. F. Franklin and R. Woollard (1976): Self-pollination effects on seed and seedling traits in Noble Fir. Forest Science 22: 155-159.

Sorensen, F. C. (1997): Effects of sib mating and wind pollination on nursery seedling size, growth components, and phenology of Douglas-fir seed-orchard progenies. Canadian Journal of Forest Research 27: 557-566.

SORENSEN, F. C. (1999): Relationship between self-fertility, allocation of growth, and inbreeding depression in three coniferous species. Evolution 53: 417-425.

Stoenr, M., A. YanchuK, C. Y. XIE and L. SANChez (2008): Gain and diversity in advanced generation coastal Douglas-fir selections for seed production populations. Tree Genetics \& Genomes 4: 193-200.

Wang, T., S. N. Aitken, J. H. Woods, K. Polsson and S. MAGNussen (2004): Effects of inbreeding on coastal Douglas fir growth and yield in operational plantations: a model-based approach. Theor. Appl. Genet. 108: 1162-1171.

Woods, J. H., T. WANG and S. N. AITKEN (2002): Effects of inbreeding on coastal Douglas-fir: Nursery performance. Silvae. Genet. 51: 163-170.

YAZDANI, R. and D. LINDGREN (1991): The impact of selfpollination on production of sound selfed seeds. In: Fineschi, S., Malvolti, M. E., Cannata, F. and HatteMER, H. H. (Eds.), Biochemical markers in the population genetics of forest trees. SPB Academic Publishing bv, The Hague, pp. 143-147. 